University of Nebraska - Lincoln

DigitalCommons@University of Nebraska - Lincoln

7-19-2013

\title{
Deriving Hourly Evapotranspiration Rates with SEBS: A Lysimetric Evaluation
}

\author{
Prasanna H. Gowda \\ USDA-ARS, prasanna.gowda@ars.usda.gov \\ Terry A. Howell \\ USDA-ARS, Terry.Howell@ars.usda.gov \\ George Paul \\ Kansas State University \\ Paul D. Colaizzi \\ USDA-ARS, Paul.Colaizzi@ARS.USDA.GOV \\ Thomas H. Marek \\ Texas AgriLife Research \\ See next page for additional authors
}

Follow this and additional works at: https://digitalcommons.unl.edu/usdaarsfacpub

Gowda, Prasanna H.; Howell, Terry A.; Paul, George; Colaizzi, Paul D.; Marek, Thomas H.; Su, Bob; and Copeland, Karen S., "Deriving Hourly Evapotranspiration Rates with SEBS: A Lysimetric Evaluation" (2013). Publications from USDA-ARS / UNL Faculty. 1842.

https://digitalcommons.unl.edu/usdaarsfacpub/1842

This Article is brought to you for free and open access by the U.S. Department of Agriculture: Agricultural Research Service, Lincoln, Nebraska at DigitalCommons@University of Nebraska - Lincoln. It has been accepted for inclusion in Publications from USDA-ARS / UNL Faculty by an authorized administrator of DigitalCommons@University of Nebraska - Lincoln. 
Authors

Prasanna H. Gowda, Terry A. Howell, George Paul, Paul D. Colaizzi, Thomas H. Marek, Bob Su, and Karen S. Copeland 
Special Section: Remote

Sensing for Vadose Zone Hydrology

Prasanna H. Gowda*

Terry A. Howell

George Paul

Paul D. Colaizzi

Thomas H. Marek

Bob Su

Karen S. Copeland

Surface Energy Balance System (SEBS) is one of the widely used surface EB methods for deriving ET rates from remote sensing data. It does not require subjective selection of hot and cold pixels for deriving ET. However, the SEBS has never been evaluated for its ability to estimate ET using lysimetric measurements. In this study, we evaluated the SEBS for estimating ET using Landsat 5 satellite data for summer crops in the Southern High Plains. Performance statistics indicated that SEBS performance was equally good in estimating hourly ET on both dryland and irrigated fields.

P.H. Gowda, T.A. Howell, P.D. Colaizzi, and K.S. Copeland, USDA-ARS Conservation and Production Research Laboratory, P.O. Drawer 10, Bushland, TX 79012; G. Paul, Dep. of Agronomy, Kansas State Univ., Manhattan, KS 66506; T.H. Marek, Texas Agrilife Research, 6500 Amarillo Blvd. W., Amarillo, TX 79016; B. Su, Geo-information Science and Earth Observation (ITC), Univ. of Twente, 7500 AE Enschede, the Netherlands. *Corresponding author (Prasanna.Gowda@ars.usda.gov).

Vadose Zone J.

doi:10.2136/vzj2012.0110

Received 11 July 2011.

(c) Soil Science Society of America

5585 Guilford Rd., Madison, WI 53711 USA. All rights reserved. No part of this periodical may be reproduced or transmitted in any form or by any means, electronic or mechanical, including photocopying, recording, or any information storage tocopying, recording, or any information storage
and retrieval system, without permission in writing from the publisher.

\section{Deriving Hourly Evapotranspiration Rates with SEBS: A Lysimetric Evaluation}

Numerous energy balance (EB) algorithms have been developed to use remote sensing data for mapping evapotranspiration (ET) on a regional basis. Adopting any single or combination of these models for an operational ET remote sensing program requires a thorough evaluation. The Surface Energy Balance System (SEBS) was evaluated for its ability to estimate hourly ET rates of summer tall and short crops grown in the Texas High Plains by using 15 Landsat 5 Thematic Mapper scenes acquired during 2006 to 2009. Performance of SEBS was evaluated by comparing estimated hourly ET values with measured ET data from four large weighing lysimeters, each located at the center of a 4.3 ha field in the USDA-ARS Conservation and Production Research Laboratory in Bushland, TX. The performance of SEBS in estimating hourly ET was good for crops under both irrigated and dryland conditions. A locally derived, surface albedo-based soil heat flux $(G)$ model further improved the $G$ estimates. Root mean square error and mean bias error were 0.11 and $-0.005 \mathrm{~mm} \mathrm{~h}^{-1}$, respectively, and the Nash-Sutcliff model efficiency was 0.85 between the measured and calculated hourly ET. Considering the equal or better performance with a minimal amount of ancillary data as compared to with other EB algorithms, SEBS is a promising tool for use in an operational ET remote sensing program in the semiarid Texas High Plains. However, thorough sensitivity and error propagation analyses of input variables to quantify their impact on ET estimations for the major crops in the Texas High Plains under different agroclimatological conditions are needed before adopting the SEBS into operational ET remote sensing programs for irrigation scheduling or other purposes.

Abbreviations: ASL, atmospheric surface layer; ASTER, Advanced Spaceborne Thermal Emission and Reflection Radiometer; BAS, bulk atmospheric similarity; CPRL, Conservation and Production Research Laboratory; EB, energy balance; EC, eddy covariance; ETM+, Enhanced Thematic Mapper Plus; IRT, infrared thermometer; LAl, leaf area index; MBE, mean bias error; METRIC, Mapping Evapotranspiration with Internalized Calibration; MODIS, Moderate Resolution Imaging Spectrometer; MOS, Monin-Obukhov similarity; NDVI, normalized difference vegetation index; NSE, Nash-Sutcliffe efficiency; PBL, planetary boundary layer; SEBAL, Surface Energy Balance Algorithm for Land; SEBI, Simplified Surface Energy Balance Index; SEBS, Surface Energy Balance System; Thematic Mapper, TM.

Evapotranspiration is a key component of the water balance in the soilvegetation-atmosphere continuum (Yang et al., 2006). Consequently, it is a critical element in the energy, hydrologic, carbon, and nutrient cycles. ET includes water evaporation from land and water surfaces and transpiration by vegetation. Therefore, it is a major consumptive use of irrigation water and precipitation on cropland, particularly in semiarid and arid regions. Components of the surface EB and ET can be measured using conventional techniques such as the Bowen ratio, eddy covariance (EC), and most accurately with properly operated and representative large lysimeter systems over homogenous surfaces. However, these systems are representative only at local scales and do not provide spatial trends (or distribution) at a regional scale due to heterogeneity of land surfaces and the dynamic nature of heat transfer processes over space (Su, 2002), especially in regions with highly advective climatic conditions. Since ET requires a large amount of energy to change water from liquid to gas phase in the environment, accurate estimations of radiation and turbulent heat fluxes in land-atmosphere exchanges are important in research applications regarding water resources management, hydrologic processes, climate change, terrestrial ecology, and numerical weather forecasting on a regional scale (Su et al., 2005). In the past, thermal remote sensing has been accepted as the most feasible means to provide spatially distributed regional ET on land surfaces (Park et al., 1968; Jackson, 1984; Allen et al., 2007a). Remote sensing based EB models can be used to convert satellite sensed radiances into land surface based characteristics such as albedo, leaf area index (LAI), vegetation indices, surface emissivity, and surface temperature to estimate ET as a residual of the land surface $\mathrm{EB}$ equation as defined by: 
$\mathrm{LE}=R_{\mathrm{N}}-G-H$

where $R_{\mathrm{N}}$ is the net radiation resulting from the energy budget of short and long wave radiation, $\mathrm{LE}$ is the latent heat flux from ET, $G$ is the soil heat flux into the ground, and $H$ is the sensible heat flux (all terms in units of $\mathrm{W} \mathrm{m}^{-2}$ ) to the atmosphere. $\mathrm{LE}$ can be converted to $\mathrm{ET}\left(\mathrm{mm} \mathrm{h}^{-1}\right.$ or $\left.\mathrm{mm} \mathrm{d}^{-1}\right)$ by dividing it by the latent heat of vaporization $\left(\lambda_{\mathrm{v}} ; 2.45 \mathrm{MJ} \mathrm{kg}^{-1}\right)$, the density of water $\left(\rho_{\mathrm{w}} ; \sim 1.0 \mathrm{Mg} \mathrm{m}^{-3}\right)$, and an appropriate time constant (e.g., $3600 \mathrm{~s} \mathrm{~h}^{-1}$ for hourly ET).

Numerous remote sensing algorithms are available today for estimating magnitude and trends in regional ET. These models include the two-source model (Norman et al., 1995; Kustas and Norman, 1996), where the EB of soil and vegetation are modeled separately and then combined to estimate total LE; the Surface Energy Balance Algorithm for Land (SEBAL) (Bastiaanssen et al., 1998a, 1998b); and the Mapping Evapotranspiration with Internalized Calibration (METRIC) Allen et al., 2007a, 2007b). Both SEBAL and METRIC use "hot" and "cold" pixels to develop an empirical temperature difference equation for estimating $\mathrm{H}$. In a related approach, the SEBS (Su, 2002) estimates $H$ based on the contrast between wet and dry areas. Other models include the Simplified Surface Energy Balance Index (SEBI) (Menenti et al., 2001; Roerink et al., 2000); the aerodynamic temperature parameterization models proposed by Crago et al. (2004); the beta ( $\beta$ ) approach (Chehbouni et al., 1996); and most recently the ET mapping algorithm (Loheide and Gorelick, 2005) and SSEB (Senay et al., 2007; Gowda et al., 2009a) methods. A detailed review of different ET algorithms is presented in Gowda et al. (2008).

The Surface Energy Balance System has been evaluated in the United States and Europe and applied for mapping ET at the field (Su et al., 2005; Paul et al., 2011), regional (Ma et al., 2011), and global scales (McCabe et al., 2009; Vinukollu et al., 2011). Su et al. (2005) evaluated SEBS with two independent, high quality datasets that were collected at the field scale during the Soil MoistureAtmosphere Coupling Experiment in the humid Walnut Creek agricultural watershed near Ames, Iowa. Meteorological and EC measurements from 10 locations within the watershed were used to estimate and compare fluxes during a period of rapid vegetation growth and varied hydrometeorology. Results indicated that ET estimates from the SEBS were close to 85 to $90 \%$ of the measured ET values from the EC systems for both corn and soybean surfaces. In the same study, regional fluxes were calculated using Landsat Enhanced Thematic Mapper Plus (ETM+) data of a clear day during the field experiment. Results at the regional scale showed that ET prediction accuracies were strongly related to crop type with improved ET estimates for corn surfaces compared with those of soybean. Differences between the observed and predicted ET values were approximately $5 \%$. Furthermore, McCabe and Wood (2006) used thermal data from Landsat ETM+ (60 m), Advanced Spaceborne Thermal Emission and Reflection Radiometer
(ASTER; $90 \mathrm{~m}$ ), and Moderate Resolution Imaging Spectrometer (MODIS; $1020 \mathrm{~m}$ ) sensors to independently estimate ET using the SEBS. A high degree of consistency was observed between the flux retrievals from both the ETM+ and ASTER data while results of using the MODIS data failed to discriminate the influence of heterogeneity in land use at the field scale.

An evaluation study by van der Kwast et al. (2009) with ASTER data acquired over the Spectra bARax Campaign experiment site at Barrax in the La Mancha region of Spain $\left(2^{\circ} 12^{\prime} 0^{\prime \prime}\right.$ W; $39^{\circ} 3^{\prime} 0^{\prime \prime}$ $\mathrm{N})$ during the summer of 2004 reported that the SEBS was capable of estimating $H$ to the same order of magnitude as tower-based flux (EC and large aperture scintillometers) observations. However, the SEBS underestimated $H$ fluxes especially over dry and sparsely vegetated areas. This is consistent with the results reported in Ma et al. (2011) using ASTER data for comparisons, with EC data in the Heigh River Basin of northwest China. In the same study, sensitivity analyses of the SEBS-derived $H$ fluxes to errors in input data indicated that a $0.5^{\circ} \mathrm{K}$ difference in land surface temperature can deviate the estimated $H$ fluxes by up to $70 \%$ followed by surface aerodynamic parameters with errors up to $50 \%$. They also reported that the accuracy of $H$ fluxes with empirically derived surface aerodynamic properties was similar to those using field measurements.

Timmermans et al. (2011) reported that there can be significant uncertainties in SEBS-derived turbulent flux estimations on tall crop surfaces (corn in this case) as the original parameterization for roughness height affecting heat is valid only for short vegetation. This is contradictory to the results reported in Su et al. (2005) where they reported better prediction of energy fluxes over corn surfaces than over soybean. This contradiction may be due to the fact that Timmermans et al. (2011) used the Soil Canopy Observation, Photochemistry and Energy fluxes model for evaluating the SEBS instead of measured flux data. Recently, Gao et al. (2011) coupled SEBS with a topography algorithm to estimate actual daily ET over heterogeneous terrain from MODIS data in northern China and reported significant improvements in the prediction of the $H$ fluxes. Overall, SEBS is a more robust EB algorithm as it does not require selection of hot and cold pixels as in the case of SEBAL and METRIC. However, SEBS has been evaluated only with EC and/or large aperture scintillometers, mostly in humid regions, that can have average EB closure errors of up to 30\% (Oncley et al., 2000; Chavez et al., 2009a; Gowda et al., 2010a, 2010b). In some cases, flux footprints of EC systems were smaller than with Landsat and/or MODIS pixels (e.g., Su et al., 2005; McCabe and Wood, 2006). Furthermore, the SEBS has never been evaluated using lysimetric measurements. Therefore, the main objective of this study was to evaluate the SEBS algorithm for its ability to estimate hourly ET in the Southern High Plains region using lysimetric data. The Southern High Plains is located in the South Central United States and is one of the most extensively irrigated semiarid regions in the world where crop water demand far exceeds rainfall. 


\section{Surface Energy Balance Systems}

The Surface Energy Balance System (Su, 2002) is a single source model that was developed by extending the SEBI concept. It consists of a set of tools for determining physical parameters (broadband albedo, surface emissivity, surface temperature, vegetation fraction, etc.) from remote sensing data, an extended dynamic model for roughness length regarding heat transfer, and a formulation for determining the evaporative fraction based on EB for the limiting (wet and dry) cases. The system requires meteorological data such as air temperature, humidity, and wind speed measured at a reference height.

In SEBS, ET is computed as the residual term from the land surface $\mathrm{EB}$ as shown in Eq. [1]. The $R_{\mathrm{N}}$ is calculated as a result of the energy budget between the short and long wave radiation terms:

$R_{\mathrm{N}}=(1-\alpha) R_{\mathrm{S}}+\varepsilon R_{\mathrm{L}}-\varepsilon \sigma T_{\mathrm{s}}^{4}$

where $R_{\mathrm{S}}$ is incoming shortwave radiation $\left(\mathrm{W} \mathrm{m}^{-2}\right)$, $\alpha$ is a surface albedo (dimensionless), and $R_{\mathrm{L}}$ is incoming long wave radiation $\left(\mathrm{W} \mathrm{m}{ }^{-2}\right.$ ) or downward thermal radiation flux originating from the atmosphere, $\varepsilon$ is the surface emissivity (dimensionless) based on the soil and vegetative broadband thermal spectral emissivities (a function of LAI or normalized difference vegetation index [NDVI]), $\sigma$ is the Stefan-Boltzmann constant $\left(5.67 \times 10^{-8} \mathrm{~W} \mathrm{~m}^{-2} \mathrm{~K}^{-4}\right)$, and $T_{\mathrm{s}}$ is the surface temperature $\left({ }^{\circ} \mathrm{K}\right)$. Soil heat flux $(G)$ in SEBS (Su, 2002) is calculated as:

$G=R_{\mathrm{N}}\left[\Gamma_{\mathrm{c}}+\left(1-f_{\mathrm{c}}\right)\left(\Gamma_{\mathrm{s}}-\Gamma_{\mathrm{c}}\right)\right]$

where $\Gamma_{\mathrm{c}}$ and $\Gamma_{\mathrm{s}}$ are the $G / R_{\mathrm{N}}$ ratio for full vegetation canopy and bare soil conditions, respectively, and $f_{\mathrm{c}}$ is the fraction of vegetation cover (dimensionless). The $f_{\mathrm{c}}$ term is used to interpolate the $G / R_{\mathrm{N}}$ ratio between the full vegetation cover and bare soil conditions. It is assumed that $\Gamma_{c}=0.05$ (Monteith, 1973) and $\Gamma_{s}=0.315$ (Kustas and Daughtry, 1990).

The Surface Energy Balance System uses a dynamic model for thermal roughness (Su et al., 2001), bulk atmospheric similarity (BAS) (Brutsaert, 1999) theory for planetary boundary layer (PBL) scaling (Wyngaard, 1990), and the Monin-Obukhov similarity (MOS) theory (Monin and Obukhov, 1954) for atmospheric surface layer (ASL) scaling. This allows application of SEBS for both local and regional scales under all stable atmospheric regimes. For unstable conditions, a criterion proposed by Brutsaert (1999) is used to determine appropriate scaling (BAS or MOS) for a given situation. For stable conditions, functions given by Brutsaert (1982) and Beljaars and Holtslag (1991) are used for PBL and ASL scaling, respectively. In the ASL, the similarity relationships for mean wind speed $(u)$ and temperature $\left(\Delta t=\theta_{0}-\theta_{\mathrm{a}}\right)$ profiles are derived using MOS theory as:

$$
\begin{aligned}
& u=\frac{u_{*}}{k}\left[\ln \left(\frac{z-d_{0}}{z_{0 \mathrm{~m}}}\right)-\Psi_{\mathrm{m}}\left(\frac{z-d_{0}}{L}\right)+\Psi_{\mathrm{m}}\left(\frac{z_{0 \mathrm{~m}}}{L}\right)\right] \\
& \theta_{0}-\theta_{\mathrm{a}}=\frac{H}{k u_{*} \rho_{\mathrm{a}} C_{\mathrm{p}}}\left[\ln \left(\frac{z-d_{0}}{z_{0 \mathrm{~h}}}\right)-\Psi_{\mathrm{h}}\left(\frac{z-d_{0}}{L}\right)+\Psi_{\mathrm{h}}\left(\frac{z_{0 \mathrm{~h}}}{L}\right)\right]
\end{aligned}
$$

where $u_{*}$ is the friction velocity calculated as $\left(\tau_{0} / \rho_{\mathrm{a}}\right)^{1 / 2}, \tau_{0}$ is the surface shear stress $\left(\mathrm{kg} \mathrm{m} \mathrm{s}^{-2}\right), \rho$ is the air density $\left(\mathrm{kg} \mathrm{m}^{-3}\right), k$ is the von Karman's constant $(\sim 0.41), z$ is the height above the surface $(\mathrm{m})$, $d_{0}$ is the zero plane displacement height $(\mathrm{m}), z_{0 \mathrm{~m}}$ is the roughness height for momentum transfer $(\mathrm{m}), \theta_{0}$ is the potential air temperature at surface $(\mathrm{K}), \theta_{\mathrm{a}}$ is the potential air temperature at $z(\mathrm{~K}), C_{\mathrm{p}}$ is the specific heat capacity of air $\left(\sim 1013 \mathrm{~J} \mathrm{~kg}^{-1{ }^{\circ}} \mathrm{C}^{-1}\right), z_{0 \mathrm{~h}}$ is the scalar roughness height for heat transfer $(\mathrm{m}), \Psi_{\mathrm{m}}$ and $\Psi_{\mathrm{h}}$ are the stability correction functions for momentum and sensible heat transfer, respectively, and $L$ is the Monin-Obukhov length ( $\mathrm{m}$ ) defined as:

$L=-\frac{\rho_{\mathrm{a}} C_{\mathrm{p}} u_{*}^{3} \theta_{\mathrm{v}}}{k g H}$

where $g$ is the acceleration due to gravity $\left(9.8 \mathrm{~m} \mathrm{~s}^{-2}\right)$ and $\theta_{\mathrm{v}}$ is the potential virtual temperature near the surface $(\mathrm{K})$.

Roughness height for heat transfer $\left(z_{0 h}\right)$ is an important parameter in the estimation of heat transfer between the land surface and the surrounding atmosphere. It is a function of surface characteristics, thermal state of the surface, and atmospheric flow. It can be derived as:

$z_{0 \mathrm{~h}}=z_{0 \mathrm{~m}} / \exp \left(\mathrm{kB}^{-1}\right)$

where $\mathrm{kB}^{-1}$ is a dimensionless heat transfer coefficient called the inverse Stanton number. In SEBS, an extended model of Su et al. (2001) that consists of three terms used to estimate the $\mathrm{kB}^{-1}$ as follows:

$$
\begin{aligned}
\mathrm{kB}^{-1} & =\frac{k C_{\mathrm{d}}}{4 C_{\mathrm{t}} \frac{u_{*}}{u(b)}\left(1-e^{-n_{\mathrm{ec}} / 2}\right)} f_{\mathrm{c}}^{2} \\
& +2 f_{\mathrm{c}} f_{\mathrm{s}} \frac{k\left(u_{*} / u(b)\right)\left(z_{0 \mathrm{~m}} / h\right)}{C_{\mathrm{t}}^{*}}+\mathrm{kB}_{\mathrm{s}}^{-1} f_{\mathrm{s}}^{2}
\end{aligned}
$$

The first term in Eq. [8] physically and geometrically follows the Choudhury and Monteith (1988) model for full canopy, the second term accounts for the interaction between the vegetation and soil surface, and the third term is for the bare soil surface value given by Brutsaert (1982). In this equation, $C_{\mathrm{d}}$ is the drag coefficient of the foliage with a value of $0.2 ; C_{\mathrm{t}}$ and $C_{\mathrm{t}}{ }^{*}$ are the heat transfer coefficients of the leaf and soil, respectively; $n_{\mathrm{ec}}$ is 
the within-canopy wind speed profile extinction coefficient, $f_{\mathrm{s}}$ is the soil fraction coverage, and $u(b)$ is the horizontal wind speed at the canopy top $\left(\mathrm{m} \mathrm{s}^{-1}\right)$. The $C_{\mathrm{t}}$ varies between $0.005 \mathrm{~N}$ and $0.075 \mathrm{~N}$ where $N$ is the number of sides of a leaf that participates in the heat exchange and $C_{\mathrm{t}}{ }^{*}$ is calculated as:

$C_{\mathrm{t}}^{*}=\operatorname{Pr}^{2 / 3} \operatorname{Re}^{*-1 / 2}$

$\operatorname{Re}^{*}=h_{\mathrm{s}} u^{*} / v$

where Pr is the Prandtl number, $\mathrm{Re}_{*}$ is the roughness Reynolds number, $h_{s}$ is the roughness height of soil (m), and $\nu$ is the kinematic viscosity of the air $\left(\mathrm{m}^{2} \mathrm{~s}^{-1}\right)$. The $n_{\mathrm{ec}}$ and the Brutsaert term for bare soil surface $\left(\mathrm{kB}_{\mathrm{s}}^{-1}\right)$ are calculated as:

$n_{\mathrm{ec}}=\frac{C_{\mathrm{d}} \mathrm{LAI}}{2 u_{*}^{2} / u(b)^{2}}$

$\mathrm{kB}_{\mathrm{s}}^{-1}=2.46\left(\mathrm{Re}^{*}\right)^{1 / 4}-\ln (7.4)$

The SEBS requires both wet and dry boundary conditions to estimate $H$ as defined in Eq. [1]. Under dry conditions, the calculation of $H_{\mathrm{dry}}$ is set to the available energy $\left(R_{\mathrm{N}}-G\right)$ as evaporation becomes zero due to the limitation of water availability, and $H_{\text {wet }}$ is calculated using the Penman-Monteith parameterization (Monteith, 1965, 1981) as:

$H_{\mathrm{wet}}=\frac{\left[\left(R_{\mathrm{N}}-G\right)-\frac{\rho C_{\mathrm{p}}}{r_{\mathrm{ew}}} \frac{e_{\mathrm{sat}}-e}{\gamma}\right]}{\left[1+\frac{\Delta}{\gamma}\right]}$

where $e$ is the actual vapor pressure $(\mathrm{kPa}), e_{\text {sat }}$ is the saturation vapor pressure $(\mathrm{kPa}), \gamma$ is the psychrometric constant $\left(\mathrm{kPa}^{\circ} \mathrm{C}^{-1}\right), \Delta$ is the rate of change of saturation vapor pressure with temperature $\left(\mathrm{kPa}{ }^{\circ} \mathrm{C}^{-1}\right)$, and $r_{\text {ew }}$ is the bulk surface external or aerodynamic resistance $\left(\mathrm{s} \mathrm{m}^{-1}\right)$ at the wet limit estimated under the assumption that the bulk internal resistance is zero as:

$r_{\mathrm{ew}}=\frac{1}{k u_{*}}\left[\ln \left(\frac{z-d_{0}}{z_{0 \mathrm{~h}}}\right)-\Psi_{\mathrm{h}}\left(\frac{z-d_{0}}{L_{\mathrm{w}}}\right)+\Psi_{\mathrm{h}}\left(\frac{z_{0 \mathrm{~h}}}{L_{\mathrm{w}}}\right)\right]$

The Monin-Obukhov length for the wet limit $\left(L_{\mathrm{w}}\right)$ can be determined as:

$L_{\mathrm{w}}=\frac{\rho u_{*}^{3}}{0.61 k g\left(R_{\mathrm{N}}-G\right) / \lambda}$
Finally, the relative evaporative fraction $\left(\Lambda_{\mathrm{r}}\right)$, the evaporative fraction $(\Lambda)$, and LE for each pixel in the remote sensing image is calculated as:

$\Lambda \mathrm{r}=1-\frac{H-H_{\text {wet }}}{H_{\text {dry }}-H_{\text {wet }}}$

$\Lambda=\frac{\Lambda_{\mathrm{r}}\left(R_{\mathrm{N}}-G-H_{\mathrm{wet}}\right)}{R_{\mathrm{N}}-G}$

and

$\mathrm{LE}=\Lambda(R \mathrm{~N}-G)$

The evaporative fraction $[\Lambda=\mathrm{LE} /(R \mathrm{~N}-G)]$ is used to estimate $\mathrm{LE}$, which is assumed to remain constant throughout the day and can be obtained for short periods and used for extrapolation of instantaneous LE and ET to daily values. Brutsaert and Sugita (1992) presented the assumption that the partitioning of available energy into $H$ and LE is constant (self-preservation of the available energy partitioning) or that the evaporative fraction remains almost constant during the daytime period. Zhang and Lemeur (1995) added that an evaporative fraction reflects how much of the available energy is used for ET and assumed that the instantaneous $\Lambda$ is representative of the daily energy partitioning, which is an acceptable approximation for clear-sky conditions. Crago (1996) also concluded that the $\Lambda$ has the tendency to be nearly constant during daytime periods, thus allowing the estimation of daytime evaporation from one or two estimates of the evaporative fraction during the middle of the day at the time of satellite overpass.

\section{Materials and Methods}

This study was conducted at the USDA-ARS Conservation and Production Research Laboratory (CPRL) located in Bushland, TX (Fig. 1). The geographic coordinates of the CPRL are $35^{\circ} 11^{\prime} \mathrm{N}, 102^{\circ} 06^{\prime} \mathrm{W}$, with an elevation of $1170 \mathrm{~m}$ above mean sea level. The soil in the region is a slowly permeable Pullman clay loam. The major crops produced within the study area are corn, sorghum, hard red winter wheat, and cotton. The SEBS algorithm (Su, 2002) was implemented using the ArcGIS environment. For this study, 15 cloud-free Landsat 5 Thematic Mapper (TM) scenes (resampled to a $30 \mathrm{~m}$ resolution, path 31, row $36,17: 15$ to $17: 30$ GMT), acquired during the 2006 to 2009 summer growing seasons with various short and tall crops (Table 1), were used to derive the energy and hourly ET fluxes at the land surface.

Radiometric calibration of all Landsat 5 TM images used in the study was done using the procedures provided by Chander and Markham (2003). This includes conversion of digital numbers (DN) stored in the satellite image into radiance $\left(L_{\mathrm{b}}\right)$, for each band as $L_{\mathrm{b}}=($ gain $\times \mathrm{DN})+$ bias $)$ followed by calculation of at-sensor 


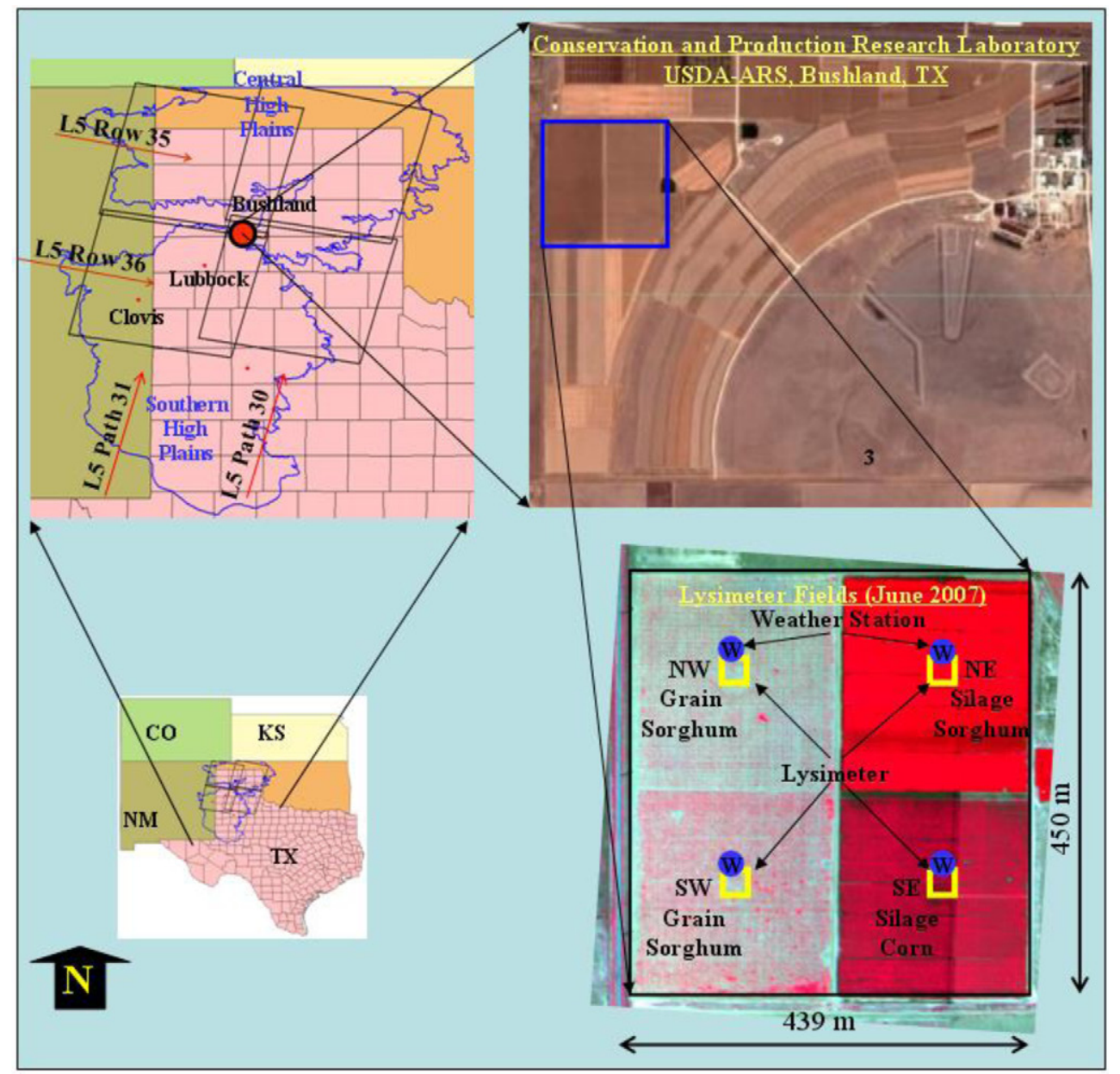

Fig. 1. Location of the Texas High Plains and four large weighing lysimeters in the USDA-ARS Conservation and Production and Research Laboratory, Bushland, TX.

reflectance $\left(\rho_{\mathrm{b}}\right)$ values by dividing the detected radiance at the sensor for each band by the incoming energy within the same shortwave band. The incoming radiance is a function of the mean solar exoatmospheric irradiance, the solar incidence angle, and the inverse square of the relative earth-to-sun distance. The planetary albedo $\left(\alpha_{\mathrm{p}}\right)$ was calculated (Liang et al., 2002) as:

$$
\begin{aligned}
\alpha_{\mathrm{p}} & =0.356 \rho_{\mathrm{b} 1}+0.130 \rho_{\mathrm{b} 3}+0.373 \rho_{\mathrm{b} 4} \\
& +0.085 \rho_{\mathrm{b} 5}+0.071 \rho_{\mathrm{b} 7}-0.0018
\end{aligned}
$$

where $\rho_{\mathrm{b} 1}, \rho_{\mathrm{b} 3}, \rho_{\mathrm{b} 4}, \rho_{\mathrm{b} 5}$, and $\rho_{\mathrm{b} 7}$ are the at-sensor reflectance for TM bands $1,3,4,5$, and 7 , respectively. The surface albedo $\left(\alpha_{\mathrm{o}}\right)$ was calculated using the equation:

$\alpha_{o}=\left(\alpha_{p}-\alpha_{p \min }\right) / \tau^{2}$

where $\alpha_{p \text { min }}$ is the planetary albedo of the darkest pixel within the image acquired (e.g., deep water body) and $\tau$ is the broadband atmospheric transmissivity derived as the ratio of incoming shortwave radiation $\left(R_{\mathrm{s} \downarrow}\right)$ and extraterrestrial solar irradiance $\left(R_{\downarrow \text { exo }}\right)$. In this study, $R_{\mathrm{s} \downarrow}$ was measured with a pyranometer (model CMP 6, Kipp and Zonen) installed at the USDA-ARS-CPRL weather station (Marek et al., 2009). For thermal infrared band images, the spectral radiance value in each pixel was converted into the at-sensor temperatures using prelaunch calibration constants by means of an inverted logarithmic formula. Surface temperature $\left(T_{s}\right)$ was calculated using surface thermal emissivity and corrected for atmospheric effects using the narrowband transmissivity derived with the atmospheric radiative transfer model MODTRAN4 v3 (Berk et al., 2003). Resulting $T_{\mathrm{s}}$ values were compared with the groundbased calibrated infrared thermometer (IRT) measurements.

An LAI model developed for the Texas High Plains by Gowda et al. (2007a) was used for this study as follows:

$\mathrm{LAI}=8.768(\mathrm{NDVI})^{3.616}$ 
Table 1. Landsat 5 Thematic Mapper data used in the study and the crops grown on four large weighing lysimeter fields in the USDA-ARS Conservation and Production Research Laboratory, Bushland, TX.

\begin{tabular}{|c|c|c|c|c|c|}
\hline \multirow[b]{2}{*}{ No. } & \multirow[b]{2}{*}{$\begin{array}{l}\text { Acquisition date } \\
\text { (Day of Year) }\end{array}$} & \multicolumn{4}{|c|}{ Lysimeter field } \\
\hline & & $\begin{array}{l}\text { NE } \\
\text { (irrigated) }\end{array}$ & $\begin{array}{l}\text { SE } \\
\text { (irrigated) }\end{array}$ & $\begin{array}{l}\mathrm{NW} \\
\text { (dryland) }\end{array}$ & $\begin{array}{l}\text { SW } \\
\text { (dryland) }\end{array}$ \\
\hline 1 & 5 June 2006 (155) & \multirow{5}{*}{$\begin{array}{r}\text { Forage } \\
\text { corn }\end{array}$} & \multirow{5}{*}{$\begin{array}{l}\text { Forage } \\
\text { sorghum }\end{array}$} & \multirow{5}{*}{$\begin{array}{l}\text { Grain } \\
\text { sorghum }\end{array}$} & \multirow{5}{*}{$\begin{array}{l}\text { Grain } \\
\text { sorghum }\end{array}$} \\
\hline 2 & 23 July 2006 (204) & & & & \\
\hline 3 & 8 Aug. 2006 (220) & & & & \\
\hline 4 & 24 Aug. 2006 (236) & & & & \\
\hline 5 & 25 Sept. 2006 (268) & & & & \\
\hline 6 & 8 June 2007 (159) & \multirow{4}{*}{$\begin{array}{r}\text { Forage } \\
\text { corn }\end{array}$} & \multirow{4}{*}{$\begin{array}{l}\text { Forage } \\
\text { sorghum }\end{array}$} & \multirow{4}{*}{$\begin{array}{l}\text { Grain } \\
\text { sorghum }\end{array}$} & \multirow{4}{*}{$\begin{array}{l}\text { Grain } \\
\text { sorghum }\end{array}$} \\
\hline 7 & 10 July 2007 (191) & & & & \\
\hline 8 & 26 July 2007 (207) & & & & \\
\hline 9 & 11 Aug. 2007 (223) & & & & \\
\hline 10 & 10 June 2008 (162) & \multirow[t]{4}{*}{ Cotton } & \multirow[t]{4}{*}{ Cotton } & \multirow[t]{4}{*}{ Cotton } & \multirow[t]{4}{*}{ Cotton } \\
\hline 11 & 26 June 2008 (178) & & & & \\
\hline 12 & 28 July 2008 (210) & & & & \\
\hline 13 & 29 Aug. 2008 (241) & & & & \\
\hline 14 & 28 May 2009 (148) & \multirow[t]{2}{*}{ Sunflower } & \multirow[t]{2}{*}{ Sunflower } & \multirow[t]{2}{*}{ Bare soil } & \multirow[t]{2}{*}{ Bare soil } \\
\hline 16 & 1 Sept. 2009 (244) & & & & \\
\hline
\end{tabular}

where NDVI is derived as $\left(\rho_{\mathrm{b} 4}-\rho_{\mathrm{b} 3}\right) /\left(\rho_{\mathrm{b} 4}+\rho_{\mathrm{b} 3}\right)$. The vegetation fraction $\left(f_{\mathrm{c}}\right)$ was calculated using the following equation (Baret et al., 1995):

$f_{\mathrm{c}}=1-\left[\frac{\mathrm{NDVI}-\mathrm{NDVI}_{\max }}{\mathrm{NDVI}_{\min }-\mathrm{NDVI}_{\max }}\right]^{K}$

where NDVI $I_{\min }$ and NDVI $I_{\max }$ are minimum and maximum NDVI values found in the given image, and the value of $K$ is 0.46 (Jia et al., 2003). The surface roughness for momentum transport $\left(z_{0 \mathrm{~m}}\right)$ was calculated using the equation by Moran (1990) and presented in Bastiaanssen et al. (1998a):

$z_{0 \mathrm{~m}}=e^{\left(C_{1}+C_{2} \mathrm{NDVI}\right)}$

where $C_{1}$ and $C_{2}$ are derived locally using measured crop height within the lysimeter fields. Soil heat flux $(G)$ is modeled using two different parameterizations: (i) a parameterization (see Eq. [3]) provided by $\mathrm{Su}(2002)$ and (ii) as a function of $R_{\mathrm{N}}$, NDVI, $T_{\mathrm{s}}$, and $\alpha_{\mathrm{o}}$ using the parameterization given by Bastiaanssen et al. (1998a) as follows:

$G=\frac{T_{\mathrm{s}} R_{\mathrm{N}}}{\alpha_{\mathrm{o}}} C\left(1-0.978 \mathrm{NDVI}^{4}\right)$ where $C$ is regression coefficient that varies with soil properties and moisture. It can be derived locally using measured $G, R_{\mathrm{N}}$, and $\alpha_{\mathrm{o}}$ following the procedure in Bastiaanssen et al. (1998a) as:

$C=a \alpha_{\mathrm{o}}^{2}+b \alpha_{\mathrm{o}}$

In this study, $\alpha_{\mathrm{o}}$ was derived from high resolution $(0.5-1.0 \mathrm{~m})$ remote sensing data acquired over the CPRL during the Bushland Evapotranspiration and Agricultural Remote Sensing Experiment 2007 (Gowda et al., 2007b, 2009b). The $G$ and $R_{\mathrm{N}}$ values were used in determining values of $a$ and $b$ from measurements within the four lysimeter fields at the CPRL. Predicted $G$ values from both methods were evaluated to select the best method for the SEBS evaluation in this study.

The SEBS-estimated ET values were verified by comparison with hourly ET values measured by soil water mass changes in the four large monolithic precision weighing lysimeters located at the CPRL. Each lysimeter ( $3 \mathrm{~m}$ length by $3 \mathrm{~m}$ width by $2.4 \mathrm{~m}$ depth) is located in the middle of a 4.3 ha field and all four lysimeters are arranged in a block pattern [Fig. 1; Howell et al. (1995)]. Each lysimeter field covers more than three thermal and 52 visible and near infrared pixels in a Landsat 5 TM image. Dryland cropping systems are managed on two lysimeter fields (SW and NW) to the west and irrigated cropping systems are managed on two lysimeter fields to the east (SE and NE) with a 10-span lateral move sprinkler system. Each of the four lysimeter fields were equipped with one net radiometer ( $Q^{*} 7.1$, Radiation and Energy Balance Systems) and one IRT (2G-T$80 \mathrm{~F} / 27 \mathrm{C}$, Exergen) for measuring $R_{\mathrm{N}}$ and $T_{\mathrm{s}}$, respectively.

In 2006 and 2007, the SW and NW lysimeter fields were planted to dryland grain sorghum in clumps (SW) and rows (NW) as part of another research study. The irrigated SE and NE lysimeter fields were planted to forage corn and sorghum, respectively. In 2008, all four lysimeter fields were planted to cotton. In 2009, irrigated lysimeter fields were planted to sunflower and the dryland fields were clean fallow (bare). Weather data used in this study were taken from a grass reference ET weather station field ( $0.31 \mathrm{ha})$, which is a part of the Texas High Plains ET Network (Marek et al., 2009) located to the eastern side of the irrigated (NE and SE) lysimeter fields.

Finally, the SEBS was evaluated by comparing predicted $T_{\mathrm{s}}, R_{\mathrm{N}}, G$, and hourly ET with observed data. A 4 by 4 grid (16,30 m pixels) was selected at the center of each lysimeter field to extract averaged values of $T_{\mathrm{s}}, R_{\mathrm{N}}, G$, and hourly $\mathrm{ET}$ from each of the lysimeter fields. Coefficient determination $\left(R^{2}\right)$ and the slope and intercept of the regression line, root mean square error (RMSE), mean bias error (MBE), and Nash-Sutcliffe efficiency (NSE) were used in the results comparison of predicted against measured data. The $R^{2}$ describes the proportion of variability in the observed data explained by the model and it ranges from 0 to 1 with a higher value indicating a better fit (model explanation). An $R^{2}$ of 1 
together with an intercept of 0 and slope of 1 indicates a perfect "fit" between the observed and modeled data. An RMSE of 0 also indicates a perfect fit, and it is usually presented as a percent of observed mean. An RMSE less than 50\% of the observed mean is usually considered low (Moriasi et al., 2007). A MBE allows comparison of the actual deviation between the estimated and measured data where $\mathrm{MBE}=0$ indicates a "no bias" condition of the model. The NSE is a measure of the relative magnitude of the residual variance compared to a 1:1 relationship between the measured and observed data. Its value ranges between $-\infty$ and 1 , with 1 indicating a perfect fit. NSE values between 0 and 1 are generally considered as an acceptable level of model performance. More information on these performance statistics can be found in Moriasi et al. (2007).

\section{Results and Discussion}

The SEBS (Su, 2002) was implemented within an ArcInfo environment $\left(\mathrm{ESRI}^{2}\right)$ to derive $T_{\mathrm{s}}, R_{\mathrm{N}}, G, H$, and hourly ET maps for the Texas High Plains. A computer program was written in Arc Marco Language to automate the implementation process. SEBS was found to be robust as the entire program was executed in one step. The SEBS was evaluated with lysimeter data for both tall (forage corn and forage sorghum) and short crops (cotton, grain sorghum, and sunflower) including bare soil surface conditions from dryland lysimeter fields in 2009 (Table 1). The values of $C_{1}$ and $C_{2}$ in Eq. [23] to calculate $z_{0 \mathrm{~m}}$ were found to be -5.5 and 5.8 , respectively. Figure 2 illustrates the relationship between the surface albedo and $C$, the regression coefficient in Eq. [24]. This relationship yielded a regression model with an $R^{2}$ of 0.38 that can be used to estimate $C$ value for a given surface albedo in each pixel of the image as:

$C=0.0029 \alpha_{\mathrm{o}}^{2}+0.0015 \alpha_{\mathrm{o}}$

Table 2 presents statistical performances of the modeled $T_{\mathrm{s}}, R_{\mathrm{N}}$, $G$, and ET fluxes against measured data. Figure 3 illustrates the comparison of estimated $T_{\mathrm{s}}$ on the four large weighing lysimeters

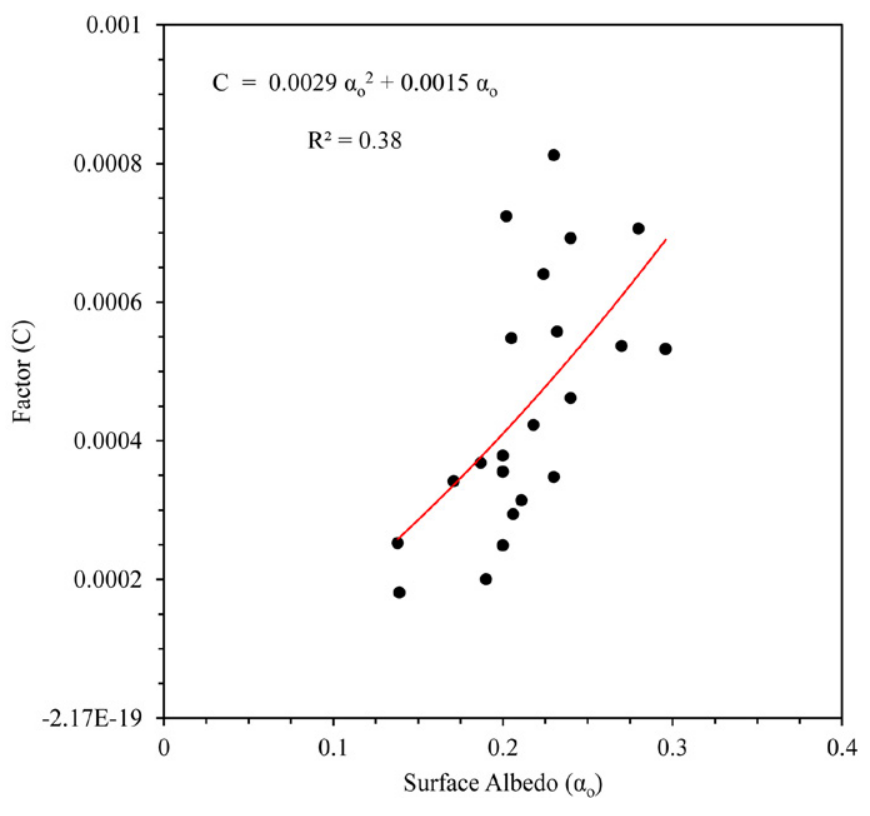

Fig. 2. Regression relationship between a factor $\mathrm{C}$ in Eq. [24] and surface albedo $\left(\alpha_{0}\right)$ derived based on field measurements at USDA-ARSConservation and Production Laboratory during 2007 and 2008 summer growing seasons in the Texas High Plains.

against measured data. As expected, observed $T_{\mathrm{s}}$ values on dryland lysimeter fields were slightly higher than that observed in irrigated lysimeter fields. Comparison of the SEBS-estimated $T_{\mathrm{s}}$ against measured data indicated equally good performance on both irrigated and dryland lysimeter fields. The observed mean $T_{\mathrm{s}}$ value $\left(31.4^{\circ} \mathrm{C}\right)$ was closely matched with the predicted mean value $\left(32.0^{\circ} \mathrm{C}\right)$. The regression model accounted for $91 \%$ of the variability in the observed data with a slope and intercept of 0.93 and $2.9^{\circ} \mathrm{C}$, respectively. The RMSE was $\sim 6.11 \%\left(1.9^{\circ} \mathrm{C}\right)$ of the mean observed $T_{\mathrm{s}}$ with an $\mathrm{MBE}$ of $-0.7^{\circ} \mathrm{C}(-2.14 \%)$. These prediction errors are similar to those reported in the literature (Chavez et al., 2009b; Anderson et al., 2004a). The NSE value of 0.90 indicated a better 1:1 performance by the SEBS in estimating $T_{\mathrm{s}}$.

Table 2. Performance statistics of the Surface Energy Balance System in the Texas High Plains.

\begin{tabular}{|c|c|c|c|c|c|c|c|c|}
\hline $\begin{array}{l}\text { Estimated } \\
\text { parameter } \dagger\end{array}$ & \multicolumn{2}{|l|}{ Mean } & RMSE & MBE & $\begin{array}{l}\text { Nash-Sutcliffe } \\
\text { efficiency }\end{array}$ & \multicolumn{3}{|c|}{ Regression } \\
\hline$T_{\mathrm{s}}\left({ }^{\circ} \mathrm{C}\right)$ & 31.4 & 32.0 & 1.92 & -0.67 & 0.90 & 0.91 & 0.93 & 2.86 \\
\hline$G_{S}\left(\mathrm{~W} \mathrm{~m}^{-2}\right)$ & 37.4 & 126.2 & 29.76 & -88.81 & -16.29 & 0.22 & 0.67 & 101.18 \\
\hline$G_{\mathrm{B}}\left(\mathrm{W} \mathrm{m}^{-2}\right)$ & 37.4 & 40.1 & 17.81 & -2.70 & 0.37 & 0.43 & 0.37 & 25.21 \\
\hline
\end{tabular}

†Abbreviations: $T_{\mathrm{s}}$, land surface temperature $\left({ }^{\circ} \mathrm{C}\right) ; R_{\mathrm{N}}$, net radiation $\left(\mathrm{W} \mathrm{m}^{-2}\right) ; G_{s}$, soil heat flux $\left(\mathrm{W} \mathrm{m}^{-2}\right)$ calculated using $\mathrm{Su}(2002) ; G_{\mathrm{B}}$, soil heat flux $\left(\mathrm{W} \mathrm{m}^{-2}\right) \mathrm{calcu}$ lated using Bastiaanssen et al. (1998a); ET, evapotranspiration rate $\left(\mathrm{mm} \mathrm{h}^{-1}\right)$. 


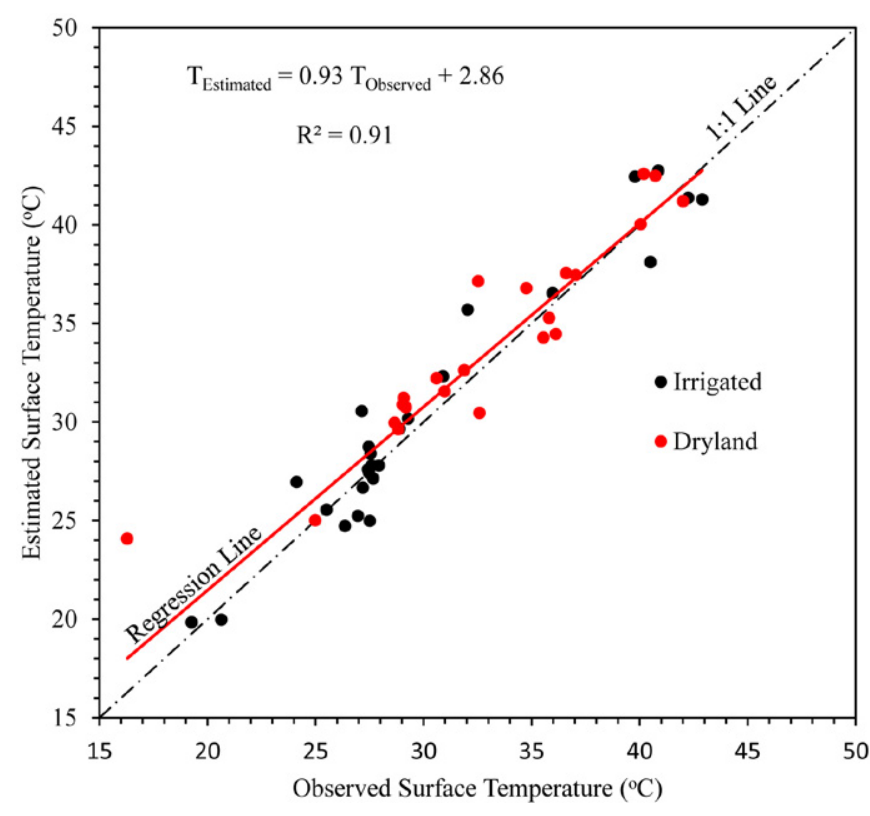

Fig. 3. Comparison of estimated land surface temperature $\left(T_{\mathrm{s}}\right)$ against observed data on four large weighing lysimeters in the USDA-ARS Conservation and Production Research Laboratory in Bushland, TX.

Figure 4 illustrates the comparison of modeled $R_{\mathrm{N}}$ fluxes on the four large lysimeters against measured data. The modeled mean $R_{\mathrm{N}}$ (596.9 $\mathrm{W} \mathrm{m}^{-2}$ ) closely matched with the observed mean value of $588.5 \mathrm{~W} \mathrm{~m}^{-2}$. Although the scales of magnitude of both modeled and observed $R_{\mathrm{N}}$ fluxes were similar, a poor 1:1 relationship was found with a NSE of 0.11 . Statistical comparison of measured and estimated $R_{\mathrm{N}}$ fluxes indicated that the regression model accounted for only $29 \%$ of the variability in the measured data and the slope and intercept of the regression line were 0.49 and $311.0 \mathrm{~W} \mathrm{~m}^{-2}$, respectively. However, the MBE and RMSE were relatively small as they were only $-1.43 \%$ and $6.11 \%$ of the observed mean $R_{\mathrm{N}}$ flux, respectively. Comparison of the predicted $R_{\mathrm{N}}$ against measured data for irrigated and dryland lysimeter fields separately indicated that MBE was slightly higher for irrigated fields (-4.04\%) than that for dryland fields $(0.56 \%)$. This bias is relatively small and could come from estimation errors in surface albedo and air emissivity. In addition, prediction errors for both fields were well within the error range reported in the literature (Key et al., 1997; Chavez et al., 2009c).

Figure 5 illustrates the comparison of estimated $G$ values using two different empirical approaches: (1) SEBS approach (Eq. [3]; Su, 2002) and (2) SEBAL approach (Eq. [24]) (Bastiaanssen et al., 1998a) with measured data on four large weighing lysimeters. The SEBS approach substantially overestimated the measured $G$ (Fig. 5). The mean estimated $G\left(126.2 \mathrm{~W} \mathrm{~m}^{-2}\right)$ was $237 \%$ higher than the measured data $\left(37.4 \mathrm{~W} \mathrm{~m}^{-2}\right)$. Not surprisingly, MBE $(-88.8 \mathrm{~W}$ $\mathrm{m}^{-2}$ ) was also substantially larger than the measured mean $G$, and the RMSE was $79.6 \%$ of the mean of the measured $G$ fluxes. The $R^{2}$

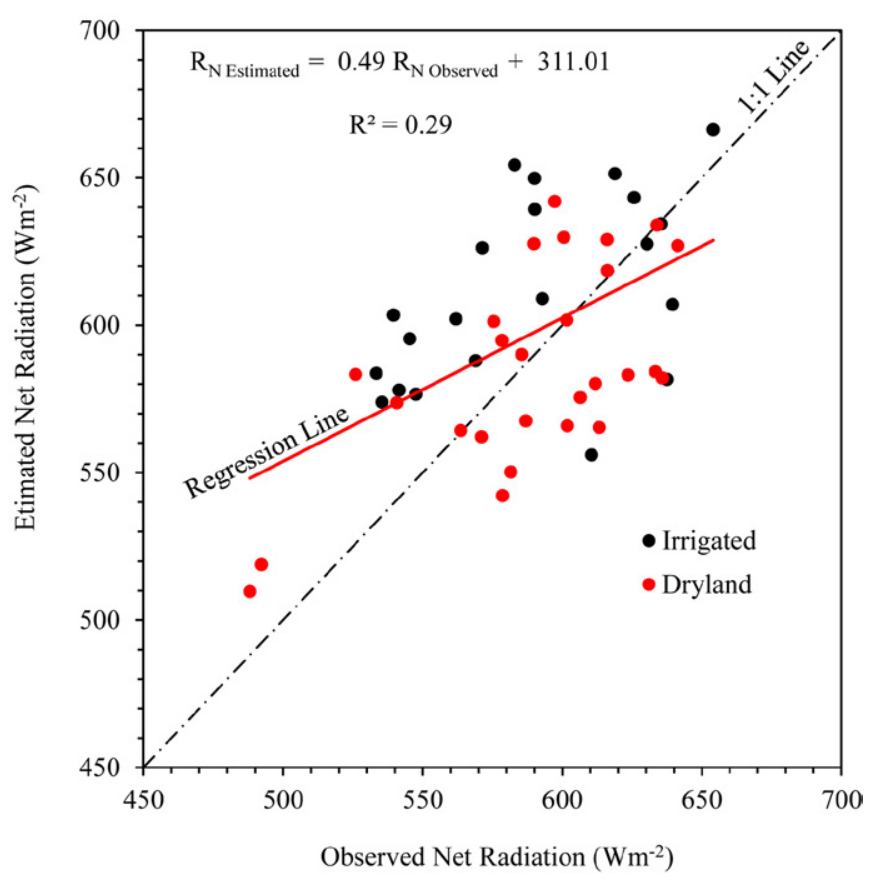

Fig. 4. Comparison of estimated instantaneous net radiation $\left(R_{\mathrm{N}}\right)$ against observed data on four large weighing lysimeters in the USDA-ARS Conservation and Production Research Laboratory, Bushland, TX.

between measured and estimated $G$ values was small (0.22) with a slope and intercept of 0.67 and $101.2 \mathrm{~W} \mathrm{~m}^{-2}$, respectively. The NSE was -16.29 , which indicated a poor performance by the model in estimating $G$. Similar results have been reported with models that use NDVI and $R_{\mathrm{N}}$ for estimating $G$ (Singh et al., 2008).

Bastiaanssen et al. (1998a) approach yielded relatively better $G$ estimates than the $\mathrm{Su}$ (2002) approach with an $R^{2}$ value of 0.39 . The slope and intercept of the regression line were 0.37 and $25.2 \mathrm{~W}$ $\mathrm{m}^{-2}$, respectively. With this approach, the MBE and RMSE were significantly reduced from -88.8 to $-2.7 \mathrm{~W} \mathrm{~m}^{-2}$ and 29.8 to 17.8 W m ${ }^{-2}$, respectively. Improvements in the $G$ estimates may be partly due to use of a locally derived surface albedo-based $C$ (see Eq. [24] and [25]). However, further calibration of the $G$ model is needed to improve the $G$ estimates. Nevertheless, other causes that can explain the poor performance of $G$ estimates include high spatial variability of $G$ and inaccuracies in the soil heat flux plate measurements.

Comparison of the SEBS-estimated hourly ET against observed data indicated that performance of the SEBS was excellent (see Fig. 6). The estimated hourly mean ET for all 16 images $(0.51 \mathrm{~mm}$ $\left.\mathrm{h}^{-1}\right)$ closely matched the observed mean of ET $\left(0.54 \mathrm{~mm} \mathrm{~h}^{-1}\right)$. The regression model explained $86 \%$ of the variability in the observed data with a slope approaching one $(0.90)$ and an intercept close to zero $\left(0.03 \mathrm{~mm} \mathrm{~h}^{-1}\right)$. The RMSE $\left(0.11 \mathrm{~mm} \mathrm{~h}^{-1}\right)$ was $20.8 \%$ of the observed mean hourly ET, and the MBE was less than $1 \%$. The NSE of 0.85 showed a strong 1:1 agreement between the estimated and observed hourly ET values with two exceptions where SEBS 


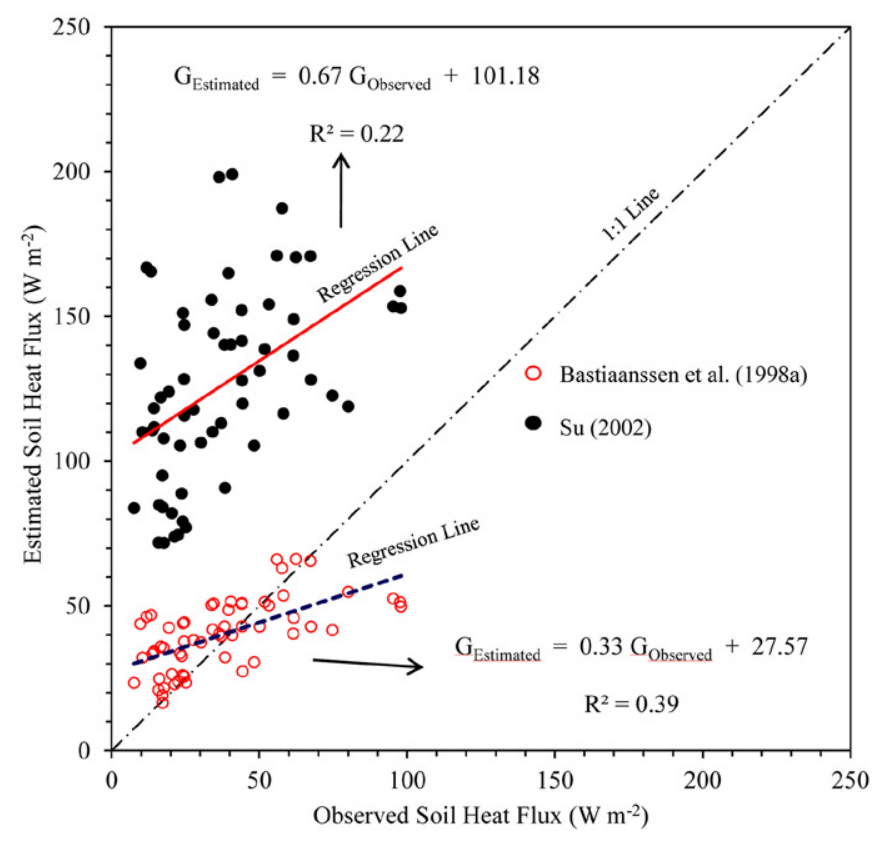

Fig. 5. Comparison of instantaneous soil heat flux $(G)$ estimates using two different empirical approaches (1) SEBS approach $(\mathrm{Su}, 2002)$ and (2) SEBAL approach (Bastiaanssen et al., 1998a) against observed data from four large weighing lysimeters in the USDA-ARS Conservation and Production Research Laboratory, Bushland, TX.

grossly over predicted ET with the 26 September 2006 image and grossly underpredicted ET with the 28 May 2009 image. In both cases, estimation errors were associated with irrigated (SE and NE) lysimeter fields where wet conditions existed during the Landsat 5 overpass. However, errors in predicted $T_{\mathrm{s}}$ values were within $1^{\circ} \mathrm{C}$, and errors in predicted $G$ were less than $4 \mathrm{~W} \mathrm{~m}^{-2}$. Unfortunately, we did not have the measured $R_{\mathrm{N}}$ values for these two dates for additional evaluation.

On 26 September 2006, both fields had tall forage crop stands (2.36 $\mathrm{m}$ tall forage corn on NE field and $2.91 \mathrm{~m}$ tall forage sorghum on SE field) with tassels on the surface on 25 September 2006 and received $25 \mathrm{~mm}$ of irrigation water on 21 September 2006. Further, vegetation fraction cover $\left(f_{\mathrm{c}}\right)$ in both fields was close to $100 \%$ with LAI values greater than $6 \mathrm{~m}^{2} \mathrm{~m}^{-2}$. However, NDVI-based LAI (Eq. [21]), $f_{\mathrm{c}}$ (Eq. [22]), and crop height models used in this study substantially underestimated the measured values. For example, the estimated LAI and $f_{\mathrm{c}}$ for the NE lysimeter field were $3.28 \mathrm{~m}^{2}$ $\mathrm{m}^{-2}$ and $66 \%$, respectively. Similar estimated values were found with SE lysimeter field with LAI and $f_{\mathrm{c}}$ of 2.42 and $58 \%$, respectively. Errors in the prediction of LAI, $f_{\mathcal{C}}, z_{0 \mathrm{~m}}$, and crop height can be attributed to NDVI saturation at moderately high LAI values $\left(\sim 2.5-3 \mathrm{~m}^{2} \mathrm{~m}^{-2}\right.$ ) (Anderson et al., 2004b) and/or the presence of tassels on the forage corn (NE) and panicles on the forage sorghum (SE) fields that increased the reflectance in the visible wavelength bands (Gitelson et al., 2003; Vogelmann and DeFelice, 2003). Therefore, it is hypothesized that the overprediction

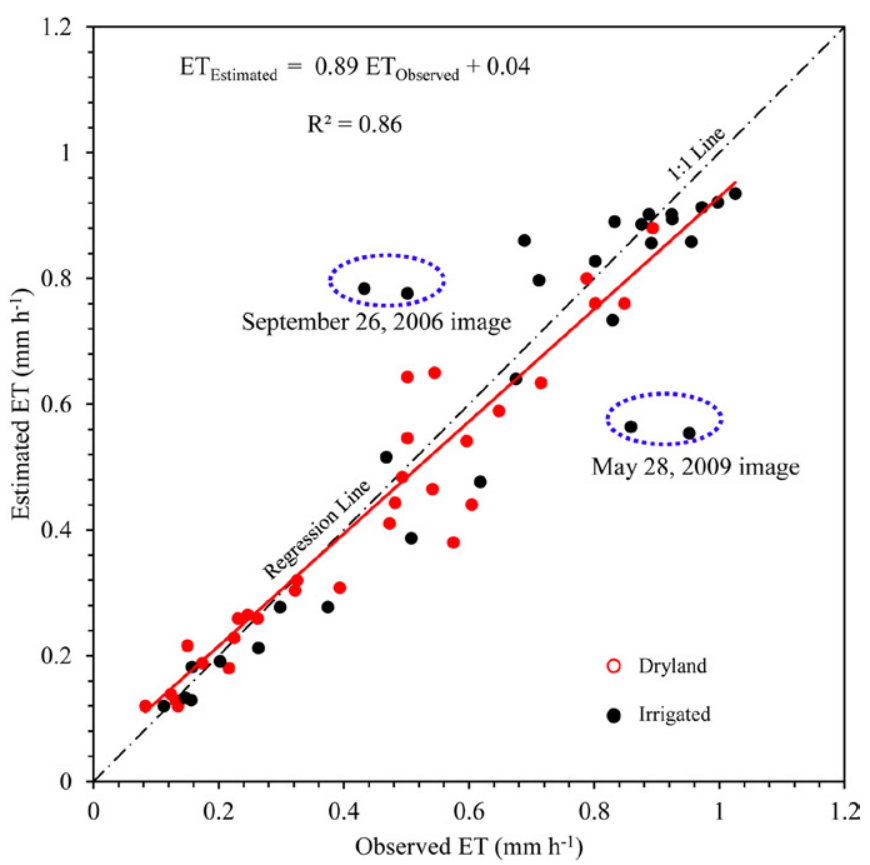

Fig. 6. Comparison of estimated hourly ET against observed data from four large weighing lysimeters in the USDA-ARS Conservation and Production Research Laboratory, Bushland, TX.

of SEBS-derived hourly ET values from the 25 September 2006 image was caused by errors in the estimated NDVI that may have then propagated into $H$ estimations.

In the case of the 28 May 2009 image, $30 \mathrm{~mm}$ of irrigation water were applied to bare soil in both NE and SE lysimeter fields on 27 May 2009 to prepare the land for planting of sunflower, and there was no vegetation. However, the $f_{\mathrm{c}}$ model (Eq. [22]) estimated $10 \%$ $f_{\mathrm{c}}$ for both fields. This may have caused the underprediction of hourly ET in the SEBS model. This clearly indicates that errors in the estimation of one of the three plant parameters (NDVI, LAI, and $f_{\mathrm{c}}$ ) can easily propagate into the estimation by all three components $\left(R_{\mathrm{N}}, G\right.$, and $\left.H\right)$ of the EB equation (Eq. [1]) and consequently cause errors in the ET estimation. Overall, accuracy levels using the SEBS for estimating hourly ET rates in the Texas High Plains were comparable or better than values reported in the literature (Gowda et al., 2008).

\section{Conclusions}

The SEBS is a single-source model requiring a minimal amount of ancillary data for estimating surface energy fluxes and instantaneous ET rates. For the first time, it was evaluated using lysimetric data for its ability to derive surface energy fluxes and hourly ET from Landsat 5 TM data in the semiarid Texas High Plains. For this purpose, SEBS was applied on 15 Landsat 5 TM images acquired during 2006 to 2009 summer growing seasons covering both tall (forage corn, forage sorghum, and sunflower) 
and short (cotton and grain sorghum) crops on lysimeter fields managed under irrigated and dryland conditions in addition to bare soil. Performance of the SEBS in estimating hourly ET was equally good for crops under both irrigated and dryland management conditions. A locally derived, surface albedo-based $G$ model (Bastiaanssen et al., 1998a) improved the $G$ estimates. Use of a better vegetation index to accurately estimate LAI, $f_{\mathrm{c}}, z_{0 \mathrm{~m}}$, and crop height or locally derived spectral models may further improve the performance of SEBS. Considering the minimal amount of ancillary data required for applying SEBS, and good performance in predicting hourly ET on both dryland and irrigated fields, it is a promising tool for an operational ET remote sensing program in the semiarid Texas High Plains. However, thorough sensitivity and error propagation analyses of input variables to quantify their impact on ET estimation for the major crops in the Texas High Plains under different agroclimatological conditions are needed before adoption of the SEBS in an operational ET remote sensing program, particularly for irrigation scheduling purposes.

\section{References}

Allen, R.G., M. Tasumi, A. Morse, R. Trezza, J.L. Wright, W. Bastiaanssen, W. Kramber, I. Lorite-Torres, and C.W. Robison. 2007b. Satellite-based energy balance for mapping evapotranspiration with internalized calibration (METRIC)-Applications. J. Irrig. Drain. Eng. 133(4):395-406. doi:10.1061/ (ASCE)0733-9437(2007)133:4(395)

Allen, R.G., M. Tasumi, and R. Trezza. 2007a. Satellite-based energy balance for mapping evapotranspiration with internalized calibration (METRIC) Model. J. Irrig. Drain. Eng. 133(4):380-394. doi:10.1061/(ASCE)0733 9437(2007)133:4(380)

Anderson, M.C., C.M.U. Neale, F. Li, J.M. Norman, W.P. Kustas, H. Jayanthi, and J.L. Chavez. 2004b. Upscaling ground observation of vegetation water content, canopy height and leaf area index during SMEX02 using aircraft and Landsat imagery. Remote Sens. Environ. 92:447-464. doi:10.1016/j. rse.2004.03.019

Anderson, M.C., J.M. Norman, J.R. Mecikalski, R.D. Torn, W.P. Kustas, and J.B. Basara. 2004a. A multi-scale remote sensing model for disaggregating regional fluxes to micrometeorological scales. J. Hydrometeorol. 5:343-363. doi:10.1175/1525-7541(2004)005<0343:AMRSMF>2.0.CO;2

Baret, F., J.P.W. Clevers, and M.D. Stevens. 1995. The robustness of canopy gap fraction estimates from the red and near infrared reflectance. A comparison between approaches for sugar beet canopies. Remote Sens. Environ. 54:141-151. doi:10.1016/0034-4257(95)00136-O

Bastiaanssen, W.G.M., M. Menenti, R.A. Feddes, and A.A. Holtslang. 1998a. A remote sensing surface energy balance algorithm for land (SEBAL): 1 . For mulation. J. Hydrol. 212-213:198-212. doi:10.1016/S0022-1694(98)002534

Bastiaanssen, W.G.M., H. Pegrum, J. Wang, Y. Ma, J. Moreno, G.J. Roerink, and T. van der Wal. 1998b. The surface energy balance algorithm for land (SEBAL): Part 2 validation. J. Hydrol. 212-213:213-229. doi:10.1016/S00221694(98)00254-6

Beljaars, A.C.M., and A.A.M. Holtslag. 1991. Flux parameterization over land surfaces for atmospheric models. J. Appl. Meteorol. 30:327-341. doi:10.1175/1520-0450(1991)030<0327:FPOLSF>2.0.CO;2

Berk, A., G.P. Anderson, P.K. Acharya, M.L. Hoke, J.H. Chetwynd, L.S. Bernstein, E.P. Shettle, M.W. Matthew, and S.M. Adler-Golden. 2003. MODTRAN4 version 3 revision 1 user's manual. Air Force Res. Lab., Space Vehicles Director ate, Air Force Mater. Command, Hanscom AFB, MA.

Brutsaert, W. 1982. Evaporation into the atmosphere. D. Reidel, Dordrecht, the Netherlands.

Brutsaert, W. 1999. Aspect of bulk atmospheric boundary layer similarity under free-convective conditions. Rev. Geophys. 37:439-451. doi:10.1029/1999RG900013

Brutsaert, W., and M. Sugita. 1992. Application of self-preservation in the diurnal evolution of the surface energy budget to determine daily evaporation. J. Geophys. Res. 97:18,377-18,382.

Chander, G., and B. Markham. 2003. Revised Landsat-5 TM radiometric calibration procedures and post-calibration dynamic ranges. IEEE Trans. Geosci. Remote Sens. 41(11):2674-2677. doi:10.1109/TGRS.2003.818464
Chavez, J.L., P.H. Gowda, T.A. Howell, and K.S. Copeland. 2009b. Radiometric surface temperature calibration effects on satellite based evapotranspiration estimation. Int. J. Remote Sens. 30(9):2337-2354. doi:10.1080/01431160802549393

Chavez, J.L., P.H. Gowda, T.A. Howell, C.M.U. Neale, and K.S. Copeland. 2009c. Estimating hourly crop ET using a two-source energy balance model and multi-spectral airborne imagery. Irrig. Sci. 28:79-91. doi:10.1007/s00271009-0177-9

Chavez, J.L., T.A. Howell, and K.S. Copeland. 2009a. Evaluating eddy covariance cotton ET measurements in an advective environment with large weighing Iysimeters. Irrig. Sci. 28:35-50. doi:10.1007/s00271-009-0179-7

Chehbouni, A., D. Lo Seen, E.G. Njoku, and B. Monteny. 1996. Examination of the difference between radiative and aerodynamic surface temperatures over sparsely vegetated surfaces. Remote Sens. Environ. 58:177-186. doi:10.1016/S0034-4257(96)00037-5

Choudhury, B.J., and J.L. Monteith. 1988. A four layer model for the heat budget of homogenous land surfaces. Q. J. R. Meteorol. Soc. 114:373-398. doi:10.1002/qj.49711448006

Crago, R.D. 1996. Conservation and variability of the evaporative fraction during the daytime. J. Hydrol. 180(1-4):173-194. doi:10.1016/00221694(95)02903-6

Crago, R., M. Friedl, W.P. Kustas, and Y. Wang. 2004. Investigation of aerodynamic and radiometric land surface temperatures. Sci. Tech. Aerosp. Rep. 42(1):201 (STAR).

Gao, Z.Q., C.S. Liu, W. Gao, and N.B. Chang. 2011. A coupled remote sensing and the Surface Energy Balance with topography algorithm (SEBTA) to estimate actual evapotranspiration over heterogeneous terrain. Hydrol. Earth Syst. Sci. 15:119-139. doi:10.5194/hess-15-119-2011

Gitelson, A.A., A. Viña, T.J. Arkebauer, D.C. Rundquist, G. Keydan, and B. Leavitt. 2003. Remote estimation of leaf area index and green leaf biomass in maize canopies. Geophys. Res. Lett. 30(5):1248. doi:10.1029/2002GL016450

Gowda, P.H., J.L. Chavez, P.D. Colaizzi, S.R. Evett, T.A. Howell, and J.A. Tolk. 2008. ET mapping for agricultural water management: Present status and challenges. Irrig. Sci. 26:223-237. doi:10.1007/s00271-007-0088-6

Gowda, P.H., J.L. Chavez, P.D. Colaizzi, T.A. Howell, R. Schwartz, and T.H. Marek. 2007a. Relationship between LAI and Landsat TM spectral vegetation indices in the Texas Panhandle. Paper presented at: 2007 ASABE Annual International Meeting, Minneapolis, MI. 17-20 June. Paper 072013.

Gowda, P.H., T.A. Howell, S. Basu, and B.R. Scanlon. 2010a. Scintillometry for ET mapping applications: A lysimetric evaluation. In: Proceedings of Remote Sensing and Hydrology Symposium, Jackson Hole, WY, 27-30 Sept. [CD-ROM]

Gowda, P.H., T.A. Howell, N. Rajan, J.L. Chavez, and S.R. Evett. 2010b. Lysimetric evaluation of eddy covariance fluxes over irrigated sunflowers in the Texas High Plains. Paper presented at: ASA, CSSA, and SSSA Annual Meetings, Long Beach, CA. 31 Oct. to 4 Nov.

Gowda, P.H., T.A. Howell, R. Vinukollu, P.D. Colaizzi, and S.R. Evett. 2009b. Evaluation of five surface energy balance approaches for mapping ET using Landsat TM data acquired during BEAREX08. Paper presented at: ASA, CSSA, and SSSA Annual Meetings, Pittsburg, PA. 1-5 Nov.

Gowda, P.H., B.R. Scanlon, T.A. Howell, C.M.U. Neale, J.L. Chavez, A.N. French, P.D. Colaizzi, and S.R. Evett. 2007b. Bushland Evapotranspiration and Agricultural Remote Sensing Experiment (BEAREX07). Paper presented at: ASA, CSSA, and SSSA Annual Meetings, New Orleans, LA. 4-8 Nov.

Gowda, P.H., G.B. Senay, T.A. Howell, and T.H. Marek. 2009a. Lysimetric evaluation of simplified energy balance approach in the Texas High Plains. Appl. Eng. Agric. 25(5):665-669.

Howell, T.A., A.D. Schneider, D.A. Dusek, T.H. Marek, and J.L. Steiner. 1995. Calibration and scale performance of Bushland weighing lysimeters. Trans. ASABE 38:1019-1024.

Jackson, R.D. 1984. Remote sensing of vegetation characteristics for farm management. SPIE Proc. 0475:81-96. doi:10.1117/12.966243

Jia, L., Z. Su, B. van den Hurk, M. Menenti, A. Moene, H.A.R. de Bruin, J.J.B. Yrisarry, M. Ibanez, and A. Cuesta. 2003. Estimation of sensible heat flux using the Surface Energy Balance System (SEBS) and ATSR measurements. Phys. Chem. Earth 28:75-88. doi:10.1016/S1474-7065(03)00009-3

Key, J.R., A.J. Schweiger, and R.S. Stone. 1997. Expected uncertainty in satellitederived estimates of the surface radiation budget at high latitudes. J. Geophys. Res. 102(C7):15,837-15,847. doi:10.1029/97JC00478

Kustas, W.P., and C.S.T. Daughtry. 1990. Estimation of soil heat flux/net radiation ratio from spectral data. Agric. For. Meteorol. 49:205-223. doi:10.1016/0168-1923(90)90033-3

Kustas, W.P., and J.M. Norman. 1996. Use of remote sensing for evapotranspiration monitoring over land surfaces. Hydrol. Sci. J. 41(4):495-516. doi:10.1080/02626669609491522

Liang, S., C.J. Shuey, A.L. Russ, H. Fang, M. Chen, C.L. Walthall, C.S.T. Daughtry, and R. Hunt, Jr. 2002. Narrowband to broadbands of land surface albedo: II. Validation. Remote Sens. Environ. 84:24-41.

Loheide, S.P., II, and S.M. Gorelick. 2005. A local-scale, high resolution evapotranspiration mapping algorithm (ETMA) with hydroecological applications at riparian meadow restoration sites. Remote Sens. Environ. 98:182-200. doi:10.1016/j.rse.2005.07.003 
Ma, W., Y. Ma, Z. Hu, Z. Su, J. Wang, and H. Ishikawa. 2011. Estimating surface fluxes over middle and upper streams of the Heigh River Basin with ASTER imagery. Hydrol. Earth Syst. Sci. 15:1403-1413. doi:10.5194/hess-15-1403-2011

Marek, T.H., D.O. Porter, T.A. Howell, N. Kenny, and P.H. Gowda. 2009. Understanding ET and its use in irrigation scheduling (a TXHPET Network series user manual). Publ. No. 09-02. Texas AgriLife Res., A\&M Univ., Amarillo, TX.

McCabe, M.F., Y.Y. Liu, R. Vinukollu, H. Su, J.P. Evans, and E.F. Wood. 2009. Comparison of latent heat flux estimates over Australia. Paper presented at: 18th World IMACS/MODSIM Congress, Cairns, Australia. 13-17 July 2009.

McCabe, M.F., and E.F. Wood. 2006. Scale influences on the remote estimation of evapotranspiration using multiple satellite sensors. Remote Sens. Environ. 105(4):271-285. doi:10.1016/j.rse.2006.07.006

Menenti, M., B.J. Choudhury, and N. Di Girolamo. 2001. Monitoring of actual evaporation in the Aral Basin using AVHRR observations and 4DDA results. In: Z. Su, and C. Jacobs, editors, Advanced earth observation-Land surface climate, Rep. USP-2, 01-02, Netherlands Remote Sens. Board, Delft. p. 79-83.

Monin, A.S., and A.M. Obukhov. 1954. Basic laws of turbulence mixing in the surface layer of the atmosphere. Tr. Akad. Nauk. SSSR Geophiz. Inst. 24(151):163-187.

Monteith, J.L. 1965. Evaporation and environment. Symp. Soc. Explor. Biol., 19:205-234.

Monteith, J.L. 1973. Principles of environmental physics. Edward Arnold Press, London.

Monteith, J.L. 1981. Evaporation and surface temperature. Q. J. R. Meteorol Soc. 107:1-27. doi:10.1002/qj.49710745102

Moran, M.S. 1990. A satellite-based approach for evaluation of the spatial distribution of evapotranspiration from agricultural lands. Ph.D. thesis, Univ. of Arizona, Tucson.

Moriasi, D.N., J.G. Arnold, M.W. Van Liew, R.L. Bingner, R.D. Harmel, and T.L. Veith. 2007. Model evaluation guidelines for systematic quantification of accuracy in watershed simulations. Trans. ASABE 50(3):885-900.

Norman, J.M., W.P. Kustas, and K.S. Humes. 1995. A two-source approach for estimating soil and vegetation energy fluxes from observations of directional radiometric surface temperature. Agric. For. Meteorol. 77:263-293. doi:10.1016/0168-1923(95)02265-Y

Oncley, S.P., T. Foken, R. Vogt, C. Bernhofer, H. Liu, Z. Sorbjan, A. Pitacco, D. Grantz, and L. Ribeiro. 2000. The EBEX 2000 field experiment. In: 14th Symposium on Boundary Layers and Turbulence, Aspen, CO. 7-11 Aug. 2000 Am. Meteorol. Soc., Boston, MA. p. 322-324.

Park, A.B., R.N. Colwell, and V.F. Meyers. 1968. Resource survey by satellite; science fiction coming true. In: Yearbook of agriculture. U.S. Gov. Print. Office, Washington, DC. p. 13-19.

Paul, G., P.H. Gowda, P.V. Varaprasad, T.A. Howell, and S.A. Staggenborg. 2011. Evaluating Surface Energy Balance System using aircraft data. In: Bearing knowledge for sustainability. Proceedings of the 2011 World Environmental and Water Resources Congress, Palm Springs, CA. 22-26 May 2011. Am. Soc. of Civil Eng., Reston, VA. p. 2777-2786.

Roerink, G.J., B. Su, and M. Menenti. 2000. S-SEBI-A simple remote sensing algorithm to estimate the surface energy balance. Phys. Chem. Earth B 25(2):147-157. doi:10.1016/S1464-1909(99)00128-8
Senay, G.B., M. Budde, J.P. Verdin, and A.M. Melesse. 2007. A coupled remote sensing and simplified surface energy balance approach (SSEB) to estimate actual evapotranspiration from irrigated fields. Sensors (Basel Switzerland) 7:979-1000. doi:10.3390/s7060979

Singh, R.K., A. Irmak, S. Irmak, and D.L. Martin. 2008. Application of SEBAL model for mapping evapotranspiration and estimating surface energy flux es in south-central Nebraska. J. Irrig. Drain. Eng. 134:273-285. doi:10.1061/ (ASCE)0733-9437(2008)134:3(273)

Su, H., M.F. McCabe, E.F. Wood, Z. Su, and J.H. Prueger. 2005. Modeling evapotranspiration during SMACEX: Comparing two approaches for local- and regional-scale prediction. J. Hydrometeorol. 6(6):910-922. doi:10.1175/ JHM466.1

Su, Z. 2002. The Surface Energy Balance System (SEBS) for estimation of turbulent fluxes. Hydrol. Earth Syst. Sci. 6:85-99. doi:10.5194/hess-6-85-2002

Su, Z., T. Schmugge, W.P. Kustas, and W.J. Massman. 2001. An evaluation of two models for estimation of the roughness height for heat transfer between the land surface and the atmosphere. J. Appl. Meteorol. 40:1933-1951. doi:10.1175/1520-0450(2001)040<1933:AEOTMF>2.0.CO;2

Timmermans, J., C. van der Tol, A. Verhoef, W. Verhoef, Z. Su, M. van Helvoirt, and L. Wang. 2011. Quantifying the uncertainty in estimates of surface-atmosphere fluxes through joint evaluation of the SEBS and SCOPE models. Hydrol. Earth Syst. Sci. Discuss. 8:2861-2893. doi:10.5194/hessd-8-2861-2011

van der Kwast, J., W. Timmermans, A. Gieske, Z. Su, A. Oliso, L. Jia, J. Elbers, D. Karssenberg, and S. de Jong. 2009. Evaluation of the Surface Energy Balance System (SEBS) applied to ASTER imagery with flux-measurements at the SPARC 2004 site (Barrax, Spain). Hydrol. Earth Syst. Sci. 13:1337-1347. doi:10.5194/hess-13-1337-2009

Vinukollu, R.K., E.F. Wood, C.R. Ferguson, and J.B. Fisher. 2011. Global estimates of evapotranspiration for climate studies using multi-sensor remote sensing data: Evaluation of three process-based approaches. Remote Sens. Environ. 115:801-823. doi:10.1016/j.rse.2010.11.006

Vogelmann, J.E., and T.P. DeFelice. 2003. Characterization of intra-annual reflectance properties of land cover classes in southeastern South Dakota using Landsat TM and ETM+ data. Can. J. Remote Sens. 29:219-229. doi:10.5589/m02-097

Wyngaard, J.C. 1990. Scalar fluxes in the planetary boundary layer-Theory, modeling, and measurement. Boundary-Layer Meteorol. 50:49-75. doi:10.1007/BF00120518

Yang, F., M.A. White, A.R. Michaelis, K. Ichii, H. Hashimoto, P. Votava, A.-X. Zhu, and R. Nemani. 2006. Prediction of continental-scale evapotranspiration by combining MODIS and Ameriflux data through support vector machine. IEEE Trans. Geosci. Rem. Sens. 44(11):3452-3461. doi:10.1109/ TGRS.2006.876297

Zhang, L., and R. Lemeur. 1995. Evaluation of daily ET estimates from instantaneous measurements. Agric. For. Meteorol. 74:139-154. doi:10.1016/01681923(94)02181-I 